\title{
Regulation of Access to Personal Data in the Archives: Issues, Trends and Challenges
}

\author{
ELENA ROMANOVA, PH.D. \\ Head of the Archival Science Department, The All-Russian Scientific and Research Institute for Archives and \\ Records Management (VNIIDAD), 82 Profsoyuznaya street, Moscow 117393 Russia \\ e-mail: romanova@vniidad.ru
}

Regulation of Access to Personal Data in the Archives: Issues, Trends and Challenges

\section{ABSTRACT}

The report is devoted to the difficulties that the archivists face when looking for a balance between the necessity to satisfy the information needs of users and the duty to protect certain types of personal data in archives. It is noted that the processes of revision of existing laws and regulations on access to information are now rising all over the world in order to meet the challenges of the rapid development of technologies and changing public mind. The necessity of reconciliation and harmonization of terms which are used in data protection activity and their definitions is emphasized. In conclusion, the author lists and characterizes the issues that, in her opinion, should be resolved at the international (or European), national levels and in the archival institutions in order to ensure better organization and transparency of access to personal data in the archives.

Key words: access to archives, data protection, personal data, use of archival documents

Regolamentazione dell'accesso ai dati personali negli archivi: problematiche, tendenze e sfide

\section{SINTESI}

L'articolo tratta delle difficoltà che gli archivisti affrontano quando guardano ad un equilibrio fra la necessità di soddisfare i bisogni dell'informazione ed il dovere di proteggere alcune tipologie di dati personali. È noto come i processi di revisione delle leggi e dei regolamenti esistenti riguardanti l'accesso alle informazioni sono attualmente all'ordine del giorno in tutto il mondo allo scopo di affrontare le sfide di un rapido sviluppo delle tecnologie e del cambiamento della mentalità pubblica. La necessità di riconciliare ed armonizzare i termini usati nell'attività di protezione dei dati e la loro definizione viene qui enfatizzata. In conclusione, l'autore elenca e caratterizza le problematiche che, a sua opinione, dovrebbero venir risolte a livello internazionale o europeo nelle istituzioni archivistiche allo scopo di assicurare una migliore organizzazione e trasparenza nell'accesso ai dati personali conservati negli archivi.

Parole chiave: accesso agli archivi, protezione dei dati, dati personali, uso dei ddocumenti archivistici

Ureditev dostopa do osebnih podatkov v arhivih: Vprašanja, trendi in izzivi

$$
\text { IZVLE } \check{C} E K
$$

Prispevek se osredotoča na težave, s katerimi se srečujejo arhivisti pri iskanju ravnotežja med potrebo po zadovoljitvi potreb po informacijah, ki jih izkazujejo uporabniki in med dolžnostj varovanja določenih vrst osebnih podatkov v arhivih. Da bi se soočili z izzivi, ki jih ponujata hiter razvoj tehnologij in spreminjanje javnega mnenja, je potrebno omeniti, da število procesov revizij obstoječih zakonov in drugih predpisov o dostopu do informacij zdaj narašča po vsem svetu. Poudarjena je potreba po usklajevanju terminologije, ki se uporablja na področju varstva podatkov in njihove definicije. Na koncu prispevka avtorica navaja vprašanja in zadeve, ki bi jih po njenem mnenju bilo potrebno rešiti na mednarodni (ali evropski), nacionalni in institucionalni ravni v arhivih, da bi zagotovili boljšo organizacijo in transparentnost dostopa do osebnih podatkov v arhivih .

Ključne besede: dostop do arhivskega gradiva, varstvo podatkov, osebni podatki, uporaba arhivskega gradiva 
Регулирование доступа к персональным данным в архивах: основные тенденции и проблемы

\section{АННОТАЦИЯ}

В докладе представлены трудности, связанные с необходимостью полноценного предоставцения архивистами информации по запросам пользователей, с одной стороны, и защиты определенных категорий персональных данных в архивах, с другой стороны. При этом отмечается общемировая тенденция к пересмотру действующих законодатемьных и нормативных актов, регулирующих доступ к информации, в связи со стремительным развитием техники, технологий и изменением общественного сознания. Подчеркивается необходимость согласования и унификации терминов, используемых для решения вопросов доступа к информации, и их определений. В заключение преАставлены те вопросы, которые, по мнению автора, следует урегулировать на международном (ики европейском), национацьном и внутриархивном уровнях Аля обеспечения большей прозрачности в организации доступа к персонацьным Аанным, содержащимся в архивных документах.

\section{Archives as holders of personal data}

Universal declaration on archives (2010), adopted at the General Assembly of the International Council on Archives in Oslo on September 2010 and endorsed by the $36^{\text {th }}$ session of the General conference of UNESCO in Paris on November 2011, recognizes "the vital necessity of archives for supporting business efficiency, accountability and transparency, for protecting citizens' rights, for establishing individual and collective memory, for understanding the past, and for documenting the present to guide future actions".

These functions of archives, which were highlighted once again in the Declaration, determine the presence in the archives of a great deal of information related to the lives of individuals and families. On the one hand, the role of archives in creating the complete and objective presentation of the historical past and of the present requires acquisition and preserving records reflecting not only the activity of various institutions, organizations, etc., but also the lives of real people who were creating the History at the macro- or micro-level and were a part of it. On the other hand, the protection of the rights of individuals requires the records, which contain the evidences of such rights, to be preserved securely in the long term.

\section{Protected data in the archives and their types}

Obviously, the archives are created and exist not only for preserving records, but for their eventual use. But if we envisage the use of all the information stored in the archives, we should first of all settle a set of problems connected with the necessity of regulation of access to different groups of information, which may be restricted for one or another reason. Thus, the first task consists in classification of all the archival information, primarily, dividing it into data of open access (or "public data") and protected data. The important point is that there is not permanently "close" data. The access can be restricted only for a certain period of time (except for very rare exceptions in certain countries), and then the data either automatically becomes public, or is subjected to declassification procedure. Besides, the access to protected data can be permitted for certain users upon their requests in accordance with the prescribed procedure.

The second stage of classification consists in defining different types of protected data. The criterions of classification and the terminology used may vary in different countries. For example, in Russia the restrictions are imposed on access to five groups of data: state secrets, official, commercial and trade secrets and confidential information about a person. Besides, each group of data of restricted access includes several different thematic groups of data. So, the imposed restrictions of access depend on the type of data we deal with. Moreover, one archival document may contain different types of protected data. That means, for example, that even after declassification of archival documents they can still be not available for everyone in reading rooms of archives, because other restrictions on access may stay actual. 


\section{Data protection reforms of recent years}

Recently, the problem of data protection, including protection of confidential personal data, has become a burning issue all over the world, once again. Data protection laws and regulations which were adopted in many countries in the 70s - 90s of XX century (in the countries of so-called "new democracy" - in the 90s and later) appeared to become out-of-date. The society has changed markedly, people expect greater transparency on the part of the governments they elect to represent them. Open government practices are tied to new technologies, programs and agreements for sharing data, and this also means ensuring a well-informed public, able to challenge the collection and sharing of their personal information. At the same time, moves toward greater transparency need to be balanced against other legitimate limits - such as the protection of confidential data. Laws and jurisprudence around the world are changing in order to conform to the new social and technological reality.

Thus, in January 2012 the European Commission put forward its EU Data Protection Reform in order to strengthen citizens' fundamental rights in the digital age and to ensure people the same data protection rights across the EU, regardless of where their data is processed. Another purpose was to facilitate business by simplifying rules for companies in the Digital Single Market. In April 2016 the new EU General data protection regulation (Regulation (EU) 2016/679) and the Directive for the police and criminal justice sector (Directive (EU) 2016/680) were adopted by the European Parliament. The new rules will become applicable two years thereafter.

The similar processes take place in different countries all over the world. Thus, in the USA the draft of Personal Data Notification \& Protection Act (2015) has been developed and proposed for the discussion in the Congress. In Canada the recommendations for amending their famous Privacy act are currently under discussion (Internet 13). The Privacy Act (1985) was a progressive and comprehensive data protection statute. At that time, Canada was a leader in privacy law. But now the specialists recognize that the Act needs renewal to reflect current thinking and experience, to bring public-sector privacy protections in Canada up to global standards.

The adoption and further modernization of laws and regulations on access to information, to personal data in particular, are of great importance for the archives. Users of the archives are first of all interested in and deal with information which is fixed in records. But access to information is regulated not only by archival laws, rules and regulations, but also by other different laws and regulations. It is extremely important that these documents do not contradict each other but on the contrary supplement one another.

The legislative processes which can be observed at international and national levels have to define the balance between the different freedoms, individual rights and public and private interests. It is also very important to determine the correct relationship between different international agreements, European and national legislation and their role in regulating the access to personal data and data protection in the archives.

\section{Terminological problems}

Here, it is necessary to emphasize the necessity of creation of the universal and comprehensive terminological system. This is an essential precondition which influences the effectiveness of laws and regulations. For the archives, in particular, it is important to have exact definitions of terms like "personal data", "sensitive data", etc. in order to define precisely what kind of information they include.

Nowadays some discrepancies in formal definitions of the terms occur. For example, According to the Regulation (EC) No 45/2001 of the European Parliament and of the Council of 18 December 2000 on the protection of individuals with regard to the processing of personal data by the Community institutions and bodies and on the free movement of such data, "personal data" mean "any information relating to an identified or identifiable natural person hereinafter referred to as "data subject"; an identifiable person is one who can be identified, directly or indirectly, in particular by reference to an identification number or to one or more factors specific to his or her physical, physiological, mental, economic, cultural or social identity" (Regulation (EC) No 45/2001, Chapter 1, article 2 (a)). In the UK Data Protection Act of 1998, for comparison, the term "personal information" refers only to living individuals (Part I, 1(1)). This is a significant addition to the definition which certainly influences 
the organization of work with personal information in the archives. We should mention that the new EU General data protection regulation also does not apply to the personal data of deceased persons. It is specified that "member States may provide for rules regarding the processing of personal data of deceased persons" (Regulation (EU) 2016/679, article 27).

It should be noted also that in international practice the English terminology is mainly used. Meanwhile, after its translation into other languages variations and inaccuracies may appear. They can distort the meaning of a term so that its coverage increases, decreases, or is shifted.

For example, after the translation of Recommendation of the Council of Europe No R (2000) 13 into the Russian language the definition of "personal data" was incorrectly interpreted, so that "personal data" was equated to information about the private life of a person which cannot be the subject of communication to the public without risking injury to the interests of that person. Thus, the meaning of the term was considerably narrowed and this mistake distorted the meaning of the Recommendation. Some international terms cannot be found in the Russian archival theory and practice. For example, the terms "sensitive data", "protected personal data" do not occur in the texts of Russian laws and regulations. Instead, there are used terms "personal data", "confidential information", "professional secrecy" and their compilations. The special law on personal data exists, but it does not cover all the possible components of the term. Moreover, it is specially mentioned in the law that it does not apply to personal data in the archives of the Russian Federation. Therefore, archivists have to consult different sources to specify what personal data should be subject to restricted access and what restrictions are imposed. Among these sources there are the civil code, labour code, tax code, code of criminal procedure, laws on personal data, on the national census, on rehabilitation of victims of political repressions, on fundamentals of protection of health of citizens in the Russian Federation, etc. Regulatory legal framework of access to archives in Russia and its terminology is characterized in the guidelines prepared in 2015 (Химина и др., 2015).

\section{5 "Access to data" or "access to archival documents"?}

Some of terms related to different kinds of data still do not have strict definitions, so the archivists should be guided by common sense when dealing with some data. It is important to emphasize that when we a talking about access to archives, we must specify the difference between access to data and access to archival documents. Thus, for instance, the document may contain both information of open access and protected data. In these cases the users have a right to obtain excerpts from the text of the document, or, for example, anonymised information which does not allow to identify the data subject. In such situations the archivists are faced with the necessity to decide themselves if the data is "anonymised" enough or there are still left some details which could point at the person mentioned in the document. It would be useful for archivists to have special methodic for realization of this kind of their professional activity. In Russia special guidelines were prepared for this purpose in 2005 (Курникова, 2005). However, we must conclude that the proposal of some archivists "to try to put yourself in data subject's place" is sometimes the only solution of this problem.

Thus, the questions of unification of professional terminology arise again and again. First of all, they should be settled at the national scale. It is very important to ensure the conformity of terms used in legislative and regulative acts which refer to data protection, not only in the archives, but in other areas as well. And besides, the national terms and their definitions should be harmonized with internationally accepted terms, in particular, with those used in international agreements.

\section{6 "Protection of archivists"}

Thus, in elaboration of archival rules and regulations (for example, reading room regulations), guidelines and methodics archivists should take into account a wide range of legislative acts, regulations, directives, etc. from different domains. The staff in the archives and the archives administrations should be very prudent in the legal issues. The need to protect the rights and interests of data subjects and data users is obvious and declared nowadays far and wide. But we should not forget that the archivists also need to ensure the protection of their own rights and interests. So all the prescribed formalities should be precisely observed in order not to admit the risk of administrative or even criminal penalties for misuse or unjustified refusal to provide information. 


\section{International conventions, agreements, recommendations}

Effectiveness of the system of data access control in the archives depends on its proper regulation at international, European and national levels and in the internal documents applicable in archives.

The promotion and protection of human rights all over the world requires close international cooperation. This cooperation includes the development of common principles of access to personal data in the archives and their protection regardless of where they are stored. To better understand each other and to avoid ambiguity in interpretation of conditions of treaties and conventions we need the multilanguage international dictionary or even standard for terms and definitions, accepted as official and applicable at the international level when dealing with issues of data access, including access to personal data in the archives.

The further development on international cooperation must be based on the past achievements in the field. One of the most important international agreements - the European Convention on $\mathrm{Hu}-$ man Rights (1953) which defends basic human rights and freedoms and was signed by all the statesmembers of the Council of Europe (47 countries). Among the others, the right to respect for private and family life is declared in the article 8 of the Convention.

The basis of the European policy of access to archival documents is formed by the Recommendation N. R (2000) 13. This is the first and only international document defining the principles of access to archival documents. Members of the EU were invited to follow common guidelines in their legislative and administrative practice. At the same time it is pointed out in the Recommendation that it is impossible to establish common access rules for everyone because of very different legal, historical and cultural contexts that surround the issue of access to archives in different countries.

\section{Regulation of access to personal data at the national level}

So the main rules for access to confidential information in the archives are to be fixed in the national laws and regulations. At the national level the regulation of access to the archives also requires the creation of a system of terms and their definitions. First of all, the precise and comprehensive definition of the term "personal information" must be fixed. Then, it is necessary to specify what types of personal information are public, and what types of personal information should be specially protected and will need access restrictions. Finally, all thematic groups of protected information are needed to be specified and described. National terms should comply with international, and at the same time they should be more concrete and circumstantial.

It is very important to use the same terminology in all national legislative acts and regulations on access to information, including personal data. Otherwise they will not be coherent and that will cause problems in their application.

The responsibility of the archives and their users (legal entities and individuals) for violation of terms and conditions of access must be fixed in legislative and normative legal documents.

However, for the archives with their specific nature it is extremely important to have the special legislation on access to personal data in the archives. If not, the archivists will have to adapt the positions of other laws and regulations to their own purposes and this is not the best decision. At the same time the archival legislation should be in coherence with other relevant national and international laws and regulations. Another solution, intermediate one, is the way chosen by Russian experts on access who developed in 2015 special guidelines for archivists on the basis of an analysis of all existing legislation relevant to this area (Химина и др., 2015).

One of the perspective solutions in regulation of access to personal data in the archives is seen in introducing of differentiated periods of limitations on access for different types of personal data. Currently, some countries have fixed terms of limited access to confidential data in the archives (for example, in Germany, Russia, etc.). However, it is not the best solution, apparently. Firstly, the prescribed periods of limited access are not always sufficient to protect interests, inward peace and dignity of the data subject or other persons concerned. And secondly, the tendency towards greater openness and accessibility of the archives involves greater flexibility in determining the terms of restricted access to personal data. 
One of the difficulties in regulation of access to personal data in the archives is connected with the fact that some functionaries have a right of access to protected information in the archives in the course of discharging their professional duties. But the archives do not always have enough information to make a proper decision about these users. It would be useful for every country to have the detailed list of categories of privileged users who have an exclusive right of access to the protected data in the archives, including personal information.

\section{Internal archival rules and regulations}

There are also some important questions which we consider desirable to be settled at the level of archival institutions. First, the authorized official person responsible for granting or denying permission to access to personal data should be determined in the internal documents of the archives. Secondly, information about people who were allowed to consult documents containing personal data, and who got a refusal should be fixed, as well as the reasons for the decision made. Thirdly, it would be convenient to develop special access application forms and a form of an obligation where the user confirms the agreement with the imposed restrictions on the use and dissemination of personal data which may be found in the requested archival documents.

\section{Conclusion}

The need to establish a comprehensive and well-functioning legislative and regulatory framework for adjustment and governing access to personal data in the archives is obvious. Thus it will be much easier for archivists to make a decision about giving a consent or a refusal to provision of different types of information per requests of different types of users. But it is recognized that "regulating access to archives is a particularly complex legal issue" (Kecskeméti and Székely, 2005, p.11). It is impossible to envisage and cover all the details which could be essential for the archives to control access to personal data. In such cases, the "Code of Ethics for Archivists" comes to our assistance as a guide and main regulator. If we carry out our duties honestly, in accordance with the universal moral principles we will almost certainly make the right decision if there is no officially prescribed solution.

\section{References}

Code of Ethics for Archivists. Available at http://www.ica.org/sites/default/files/ICA_1996-09-06_code\%20 of\%20ethics_EN.pdf (accessed on 05.05.2016).

Convention for the Protection of Human Rights and Fundamental Freedoms, the (the European Convention on human rights). Opened for signature in Rome on 4 November 1950, came into force in 1953. Available at http://www.echr.coe.int/Documents/Convention_ENG.pdf (accessed on 05.05.2016).

Data Protection Act 1998. Available at http://www.legislation.gov.uk/ukpga/1998/29/contents (accessed on 05.05.2016).

Directive (EU) 2016/680 of the European parliament and of the council of 27 April 2016 on the protection of natural persons with regard to the processing of personal data by competent authorities for the purposes of the prevention, investigation, detection or prosecution of criminal offences or the execution of criminal penalties, and on the free movement of such data, and repealing Council Framework Decision 2008/977/JHA 4.5.2016 EN Official Journal of the European Union L 119/89. Available at http://ec.europa.eu/justice/data-protection/ reform/files/directive_oj_en.pdf (accessed on 05.05.2016).

H.R.1704 - Personal Data Notification and Protection Act of 2015. Introduced into the Congress 03/26/2015. 04/29/2015 Referred to the Subcommittee on the Constitution and Civil Justice. Available at https://www. whitehouse.gov/sites/default/files/omb/legislative/letters/updated-data-breach-notification.pdf (accessed on 05.05.2016).

Kecskeméti C., Székely I. (2005). Access to Archives: A Handbook of Guidelines for Implementation of Recommendation No R (2000)13 on a European Policy on Access to Archives. Council of Europe, 2005. P. 11

Privacy Act (R.S.C., 1985, c. P-21) Available at http://laws-lois.justice.gc.ca/eng/acts/P-21/ (accessed on 05.05.2016).

Privacy Act Reform in an Era of Change and Transparency. Available at https://www.priv.gc.ca/parl/2016/ parl_sub_160322_e.asp (accessed on 05.05.2016).

Recommendation No. R (2000) 13 of the Committee of Ministers of the Council of Europe to member states 
on a European policy on access to archives (Adopted by the Committee of Ministers on 13 July 2000, at the 717th meeting of the Ministers' Deputies). Available at https://rm.coe.int/CoERMPublicCommonSearchServices/DisplayDCTMContent?documentId=09000016804cea4f (accessed on 05.05.2016).

Regulation (EC) No. 45/2001 of the European Parliament and of the Council of 18 December 2000 on the protection of individuals with regard to the processing of personal data by the Community institutions and bodies and on the free movement of such data. Official Journal L 008, 12/01/2001 P. $0001-0022$. Available at https://secure.edps.europa.eu/EDPSWEB/webdav/site/mySite/shared/Documents/EDPS/DataProt/Legislation/Reg_45-2001_EN.pdf (accessed on 05.05.2016).

Regulation (EU) 2016/679 of the European parliament and of the council of 27 April 2016 on the protection of natural persons with regard to the processing of personal data and on the free movement of such data, and repealing Directive 95/46/EC (General Data Protection Regulation) 4.5.2016 EN Official Journal of the European Union L 119/1. Available at http://ec.europa.eu/justice/data-protection/reform/files/regulation_oj_ en.pdf (accessed on 05.05.2016).

Курникова И.А. (2005). Аоступ к персональным данным: законодательство и практика (отечественный и зарубежный опыт): Методическое пособие / Росархив, ВНИИААА. М., 2005.

Химина Н.И. и Ар. (2015). Использование архивных документов, содержащих конфиденциальную информацию, охраняемую законодательством (за искцючением государственной тайны): Методические рекоменАации. (at press).

\section{SUMMARY}

The archives in all the countries preserve personal data to a greater or lesser extent depending on their history, subordination, acquisition policy. The historical, social, religious, organizational and financial conditions of the archives activities vary from country to country. This diversity does not allow elaborating the same rules of access to personal information for everyone. At the same time, the common principles must be observed in all democratic countries. These principles are defined in the Recommendation No. R (2000) 13 of the Committee of Ministers of the Council of Europe on a European policy on access to archives. Another question which needs to be settled at the international level is the creation of the multilingual data access dictionary of terms and their comprehensive definitions. This dictionary could be used as a standard for international agreements and as a guide for the national laws and regulations regarding the terminology to be used. The main rules for access to confidential information in the archives are to be fixed in the national laws and regulations. It is very desirable to have the special archival legislation on the access to personal information in the archives. Otherwise, the archivists will have to adapt the positions of other laws and regulations to their own purposes. In cases if there are no official prescriptions for terms of access to certain specific personal data, the "Code of Ethics for Archivists" may be used as regulator.

Tipology: 1.04 Professional Article

Submitting date: 15.02 .2016

Acceptance date: 20.02 .2016 
